\title{
ÚVODNÍ SLOVO
}

\section{Vážení čtenáři,}

dostává se vám do rukou první letošní číslo časopisu Obrana a strategie. Od jeho posledního vydání již uplynula řada měsíců, které byly naplněny činorodou prací redakčních orgánů a jejíž výsledek máte nyní před sebou. Uplynulé období bylo pro časopis velmi dynamické a důležité z hlediska změn, které jej v nejbližší době očekávají.

Ústav strategických studií, který byl dosud odborným garantem vydávání časopisu, končí k 31. srpnu letošního roku svoji činnost a jeho nástupnickou organizací se stane Ústav strategických a obranných studií Univerzity obrany, který uvedenou garanci převezme.

První měsíce byly také ve znamení úsilí o úspěšné zařazení časopisu do připravovaného pozitivního Seznamu recenzovaných neimpaktovaných časopisů (periodik) vydávaných v České republice, který je schvalován poradním orgánem vlády České republiky, Radou pro vědu a výzkum. Zařazení Obrany a strategie do tohoto exklusivního seznamu je nejen potvrzením jeho kvality, ale rovněž zvyšuje jeho hodnotu z hlediska hodnocení publikovaných textů v rámci evaluace vědy a výzkumu v České republice.

Kvalita je naším cílem a k jeho naplňování směřovaly i naše další aktivity. Došlo k rozšíření redakční rady a redakčního okruhu časopisu o nové zahraniční členy, získali jsme nové mediální a odborné partnery, časopis bude nově prezentován i v rámci uznávaných mezinárodních databází, např. EBSCO, SFX, Central and Eastern European Online Library aj. Rozšiřuje se okruh našich čtenárưo a daří se nám získávat i zajímavé domácí a stále častěji i zahraniční autory.

Prostřednictvím Univerzity obrany, jakožto vydavatele, získal časopis členství a zastoupení $\mathrm{v}$ organizaci PILA/Crossref. PILA (Publishers International Linking Association) a European Association of Science Editors. Těmito kroky získáváme přistup $\mathrm{k}$ nejnovějším informacím o trendech $\mathrm{v}$ oblasti publikování vědeckých textů a technickou podporu při implementaci mezinárodních edičních standardů.

A co vám přináší nejnovější vydání našeho časopisu? John T. Plant se ve svém článku zamýšlí nad současným chápáním a užíváním pojmu asymetrický boj. Zdeněk Kř́íz analyzuje závěry z bukurešt'ského summitu NATO a hodnotí současný vývoj Aliance z hlediska jejího institucionálního charakteru a poslání, Jaroslav Švestka se věnuje aktuální komparaci strategických sil a možností Ruské federace a USA. David Whetham se ve svém prrípěvku zaobírá teorií spravedlivé války a jejími morálními aspekty. Lucie Zavičáková komentuje ustavení Komise OSN pro budování míru a hodnotí dopady a možnosti její činnosti, Gerald Brettner-Messler ve svém textu pojednává o rakouském bezpečnostním dilematu a jeho odrazu na účasti při řešení krize v Čadu. Vaší pozornost si jistě zaslouží také příspěvek Miloše Balabána k problematice globální nerovnosti a její bezpečností dimenzi.

Jsme rádi, že náš časopis se stal nejen žádaným a atraktivním zdrojem odborných informací, ale rovněž prostorem pro odbornou debatu a polemiku. $\mathrm{Z}$ tohoto důvodu byl ve Volné tribuně dán prostor názorům reagujícím na kritický článek o sekuritologii, který byl uveřejněn v posledním loňském čísle časopisu. Kromě článků a debatních příspěvků vám samozřejmě přinášíme recenze odborných publikací a informační servis.

Doufáme, že Vás tematická nabídka tohoto čísla zaujme a děkujeme Vám za dosavadní čtenářskou přízeň.

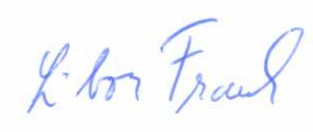

Libor Frank

Předseda Redakční rady 
